\title{
Study on the Improvement of Personal Income Tax in China - Based on the Comparison Visual of America
}

\author{
Xirong Wang ${ }^{1, a^{*}}$ \\ ${ }^{1}$ School of Management, Yulin University, China,719000 \\ a250661321@qq.com
}

Keywords: Individual income tax; Tax system; Comparison; Differences

\begin{abstract}
In order to improve China's personal income tax system, the paper analyzed the differences of individual income tax between China and America using comparative analysis method.In terms of taxpayers, deduction standard, tax rates and tax mode, there are differences of individual income tax systems between China and America, which are determined by state's tax structure, economic development, ownership and status of tax category. On the basis of summing up the strengths and experience of American individual income tax, constantly revised and improved China's individual income tax system so as to establish an individual income tax system which is suitable for China's socialist market economic development.
\end{abstract}

\section{Differences of Individual Income Tax System between China and America}

Although there are many similarities in legislation of two countries, their tax systems are significantly different in following points:

Different Taxpayer Classifications. Taxpayers of individual income tax in China are classified as resident taxpayers and non-resident taxpayers with no more subdivisions. Based on the income, taxpayers of each category pay for the tax according to uniform standards. Differently, apart from the above two categories, taxpayers include married joint taxpayers, a single individual taxpayer, householder and other categories in America in accordance with the taxpayers' identity. For different taxpayers, America individual tax system provides different term of tax, tax rates, deduction standards and different individual tax reductions.

Different Tax Rates. It can be seen through the preceding comparison: the same tax rate is used for all individual incomes exceeding the threshold, and the maximum rate of individual income is ten percentage points higher than America. In reality, the higher the tax rate and bracket, the more chance of taxpayers' tax avoidance and tax evasion, which increases the difficulties of taxing for the tax authority. 25\% - 45\% tax rate are useless in the actual implementation. Differently, the United States fully takes into account factors such as marriage and family burden and sets five reporting methods for different taxable range and tax rates. Besides, the range interval between two brackets of a low tax rate is relatively large, and that of a high tax rate slows down. This method can prevent tax evasion of high-income people more effectively and progressively.

Different Tax Mode. The principal tax mode of individual income tax in China is withholding and remitting tax monthly. Companies that taxpayers working for will pay the tax when they pay the staff salaries. Individual income tax in American has adopted annual payment through individual tax reporting. It means that at the beginning of the tax year, taxpayers need to make a tax declaration by estimating the income of this year, and then pay the tax of estimated income in four installments. At the end of the tax year, taxpayers submit official declaration form of individual income tax according to the actual income (labor income or capital gains). The government will return the overcharge and demand the payment of shortage. If the tax credit is higher than the payable tax, taxpayers not only have no need to pay tax but also have the right to get certain drawbacks and subsidies. Therefore, compared to domestic taxpayers, American taxpayers are more aware of their taxes and have a clearer understanding of government's taxing act. 


\section{Reasons for Differences of Individual Income Tax System between China and America}

Compared to developed countries, there are many problems of individual income tax system in China. However, realizing these problems doesn't mean that it is feasible to copy their models or experiences, because these differences are subjected to politics, economy, culture and other factors, including following points:

Influence of State Tax Structure. In terms of state structure, China belongs to the unitary state. Applying to the legislation of tax, the unified law of the individual income tax is enacted by people's congress. After the issue of the system of tax distribution, individual income tax is charged by the local Inland Revenue Department, but the tax amount is allocated by the central and local governments in proportion. In other words, there is only one set of unified income tax system in China. To some extent, unitary system has increased the difficulty of tax levy and management, resulting in a large number of tax evasion and avoidance behavior.

As a federal state, America decentralizes its power vertically to federal and state governments, both of which have right to charge for individual income tax. In addition, county and other units have been set up as state's subdivisions which charge for individual income tax according to state legislation. Therefore, three-level individual income tax system has formed in America, including federal income tax (national unified, setting standards annually), state income tax (excluding seven states) and local income tax (usually large cities like New York). Tax levy of hierarchical system can keep taxpayers' information more closely and prevent the tax loss effectively.

Influence of Economic Development. Economic development level is equal to the productivity development level, which is the root cause of differences between two individual income tax systems. In some way, it also determines the level of tax theory and practice in a state, and reflects the setting goal, mode and specific contents of tax regulations. The reason why personal income tax is regarded as the main tax in the United States and why it is promoted to be a complete system, clearly is its significant economic development and huge individual income.

However, China is still in the primary stage of socialism with a relatively low level of economic development. In order to promote the continuous development of a market economy, adjusting the individual income allocation is the macroeconomic management objective. Restricted by the economy, China's management system is not perfect. Its tax mode and the content are set in a relatively simple way. What's more, because of the depressed economic development level and simple economic work, provisions in individual income tax are incomplete.

Influence of Ownership. American individual income tax system is established on the foundation of its market economic system based on private ownership in which individuals are the most important market participants. Enterprise's private ownership dominates some behaviors of market participants. Government acts in this context aim at serving people andenterprises, which means government sets a variety of policies for satisfying the different interest of groups. Therefore, America individual income tax system is bound to consider the voice of various interest groups in a certain period, and establishes a multi-functional tax system by balancing the requirements of all interest groups.

However, China's market economy is based on public ownership which determines the dominant place of public-owned economic sector in social economy. What's more, economic behavior of enterprises cannot be completely broken down into economic behavior of people in such a market economy, and enterprise interests cannot be broken down into individual interest too. Consequently, Chinese government cannot position the tax reform and progress on the basis of balancing requirements of all interest groups like America, at least not currently.

\section{Main Defects of Individual Income Tax in China}

Unreasonable Classification of the Tax System. Chinese tax system has only one kind of tax nominally, but in fact it is divided into 11 tax items which are applied to different tax rates and different deduction methods. This tax system can facilitate the tax levy and management, and realize 
the taxation at source, but it is not good for balancing the distribution gap of individual income. Its unfairness can be seen from the following example.

Example 1: of taxpayer A, whose monthly wage is 3,000 Yuan and annual income is 36,000 Yuan, has no need to pay tax; taxpayer B, who has got 36,000 Yuan in a month without any income other months, is required to pay tax of $360,000 \times(1-20 \%) \times 30-2,000=4.64$ thousand Yuan.

It is very common in reality. Some professional workers with no fixed income may obtain several large incomes within one year, but their actual payable tax is much higher than that of people who have the same income. Therefore, the unfairness of the Chinese tax system is evident.

Unreasonable Tax Levy Mode. At present, for individual income tax in China, tax authorities charge individuals for their income tax by withholding at source monthly or on a transaction-by-transaction basis. Such a tax levy mode is not fair.

Example 2: There are three members of Mr. Zhang' s family. Mr. Zhang, the only wage earner, is in working condition for only six months in a year. In the six months, he earns 9,000 Yuan each month, and he has no income in the other six month. Under current tax system, the monthly payable tax for him is $(9000-3500) \times 20 \%-555=545$ Yuan, and the annual payable tax is $545 \times 6=3270$ Yuan; if collecting tax according to his annual income, his monthly wage on average is 4,500 Yuan, so the monthly payable tax is $(4500-3500) \times 3 \%=30$ Yuan, and the annual taxable amount is $30 \times 12=$ 360Yuan; if collecting tax according to his household income, the monthly income of his family is 1,500 Yuan which is out of the taxable range.

Lack of Indexation Management Mechanism. The so-called tax indexation, also known as inflation adjustment, refers to adjusting some of the items in the tax system with the price changes, automatically eliminating the impact of inflation on the actual payable tax. Individual Income Tax Law newly revised in 2011 has increased the threshold of wage and salary income to 3500 Yuan, and has also the lower the tax rate from bracket 9 to bracket 7, but it hasn't taken into account the increase rate of price and actual cost of the individual expenditure. With the increasing of economic development, education, pension, housing, medical and other expenses are increasing their importance in the expenditure structure of taxpayers, but these basic expenses have not been contained in the statutory deduction. In effect, this deduction standard without an indexation mechanism increases taxpayers' tax bracket.

Inducing Tax Evasion Easily. At present, tax evasion is very serious in China, and there are numerous means of tax evasion. Classified income tax system is not reasonable in many parts, so taxpayers can get many chances to evade tax through income dispersion and identity change. Nowadays, the definition of salary and remuneration is still relatively vague but the two differ greatly in the tax rate. It the tax rate of salary income is low, taxpayers will try to transform it into remuneration, and conversely, they will try to transform remuneration into salary income.

Example 3-3: In March 2012, one taxpayer obtained income of remuneration for 4,000 Yuan in one time, so his payable tax is $(4000-800) \times 20 \%=640$ Yuan. However, the taxpayer required the payer to pay him 4,000 Yuan in five times, and he got 800 Yuan each time. Thus, this income was not taxable.

\section{Experience of America Individual Income Tax System}

Promoting the Combination of Comprehensive Tax System and Classification Tax System. China has a vast territory, large population and complex social and economic development. Owing to imperfect modern methods of tax levy and citizens' weak tax consciousness, it is very difficult to implement comprehensive tax system. Referring to general international practice and combined with the situation of China, it is feasible for China individual income tax to adopt a comprehensive classification tax system mainly based on comprehensive tax system supplemented by classification tax system. On the basis of such a tax system, government should set strict reporting standards for individual income tax, and then promote its progress step by step for maintaining the relative stability 
for a certain period. Gradually, refine comprehensive tax items as the conditions permit, and finally realize a fully inclusive tax system.

Refining Deduction Standards. Regional economic development level differs greatly in China. The living cost and consumption expenditure in medium-sized cities is significantly higher than that of small cities and counties. Therefore, the setting of deduction standard should take into account the individual differences, changing with the number of family members, dependent children and dependent elders. "Reduction" in American individual income tax is equivalent to "threshold" in China. China can adjust the "threshold" through the Americans' experience. The adjustment is not confined into the increase and decrease but to set different brackets for alleviating the one-size-fits-all phenomenon. Furthermore, in order to avoid the influence of inflation, the deduction standard should achieve the indexation adjustment of the individual income tax by referring to citizens' consumption value index in that year and inflation rate, which is meaningful to individual income tax reform.

Making Certain of Taxpayers' Actual Income. Currently, in order to grasp the individual's actual taxable income, tax authorities should make efforts as follows: firstly, design a fixed, lifelong and unique duty paragraph for taxpayers corresponding to their ID number; second, adjust and standardize the wages income structure of workers, realize the monetization of all kinds of remuneration including all goods, securities and other benefits got through various ways, all of which should be contained into the range of salary; thirdly, units, which need to pay large income to workers who are not staff of the unit (such as the Press should pay remuneration to the author, and the training institutions should pay remuneration to external teachers) are required to mail receipt vouchers to earners; fourthly, realize the unified payment of salaries through a specified bank; fifthly, establish a information system of tax levy and management which takes ID number as the unique identification.

Establishing Supporting Mechanisms. In the long run strengthening the levy and management of the individual income tax is necessary to combine with electronic development of finance. The establishment of banking supervision system, individual declaring management system, withholding management system and cross-auditing system is helpful to collect taxpayers' information completely and efficiently. Besides, real-name system of financial assets is essential. Tax authorities ought to keep in touch with industry and commerce department and banks for realizing the sharing of taxpayers' information and achieving better management of taxpayers. What the more imperative is, tax authorities ought to complete tax registration, tax declaration, as well as tax storage, monitoring and inspection through the network. Gradually, supporting systems and measures will be established and improved for China's individual income tax, so as to make the levy and management scientific, reliable and perfect.

Paying Attention to the Reform of Overall Tax System. The proportion of indirect tax into China's total fiscal revenue is too high, so when referring to ease the tax burden, people only focus on the direct taxes of which the tax source takes a small proportion like the individual income tax, but ignore the large indirect taxes. Studies show that the influence of individual income tax on regulating income distribution in developing countries is limited. According to the specific situation in China, in order to make the tax system play an effective role in regulating income distribution, it is not feasible to concentrate on the reform individual income tax system. Adjustment on threshold is hopeless to change conditions of the poor. Conversely, taxable items ought to be increased appropriately for the rich to reduce the taxable items and amount of most people's living consumption. Therefore, if the government doesn't promote the reform of the overall tax system, or doesn't solve the problem of excessive indirect tax, it will be boastful talk that regulate income distribution efficiently and narrow the gap between the rich and the poor.

\section{References}

[1] Zhou Jie, Interpretation and prospect of China's individual income tax reform, J.Friends of Accounting.1(2014) 34-36

[2] Tian Yang,Newly revised individual income tax law, J.Guizhou Daily,.8(2013):3-6 
[3] Yi Na,On the new individual income tax reform, J.China Urban Economy.20(2014) 27-30

[4] Cai Hongbiao, Inspiration of American individual income tax rate on China's individual income tax reform,j. Special economy, 11(2013) 15- 17

[5] Yang Minghua, On improving the individual income tax system in China,J.Friends of Accounting, 17(2014) 22.

[6] Li Fang,Basic idea of the individual income tax reform in China,j.Taxation and Economy, 2(2012) $21-23$.

[7] Sun Minqian,Researches on individual income tax reform in China,D.Master Dissertation, Capital Normal University(2012) 132-134.

[8] Zhang Bingjie,On reform directions of China's individual income tax through the comparison of individual income tax in China and the United States,J.Manager Journal, 11(2013)17-19

[9] Zhu Yue,Legal reflections on improving China's individual income tax law ,Master Dissertation,J. Jilin University of Finance and Economics,9(2013)13-15

[10] RM Bird,EM Zolt(2014) The limited role of the personal income tax in developing countries,J.

Journal of Asian Economics, 16(2014) 928-946 